\title{
ANALYSIS OF FIPRONIL AND METABOLITES OF FIPRONIL IN EGGS BY LC-MS/MS
}

\author{
Nguyen Huong Giang ${ }^{1,2}$, Do Ngoc Nhan ${ }^{1,2}$, Pham Van Son ${ }^{3}$
}

Center for Drug, Cosmetic and Food Control Ho Chi Minh city ${ }^{1}$

Department of Chemical Engineering, Polytechnic University, Vietnam National University, Ho Chi Minh city ${ }^{2}$

Food Safety Management Board Ho Chi Minh city

(Received on: 18/1/2019; Revised on: 15/3/2019; Accepted on: 26/3/2019)

\section{Abstract}

\begin{abstract}
A simple, sensitive and reliable method was developed and applied to determine fipronil and its metabolites in chicken egg by means of liquid chromatography-tandem mass spectrometry (LC-MS/MS). Chicken egg samples were extracted with water and acetonitrile, added with DisQuE salt, shaken and then centrifuged. The extracts were purified by Oasis cartridge prior to analysis by LC-MS/MS. The calibration curve showed good linearity within the concentrations from 0.5 to $10.0 \mu \mathrm{g} / \mathrm{kg} \quad\left(\mathrm{R}^{2}>0.99\right)$. The average recovery rates of fipronil and its metabolites at three spiked levels of $2.0 ; 5.0$ and $10.0 \mu \mathrm{g} / \mathrm{kg}$ ranged from $93.24 \%$ to $107.89 \%$ and the relative standard deviations were less than $9.2 \%$. The LOQ of this method was of $0.6 \mu \mathrm{g} / \mathrm{kg}$ and LOD was of $0.2 \mu \mathrm{g} / \mathrm{kg}$. The method has also been successfully applied to analyze fipronil and its metabolites in the real samples.
\end{abstract}

Keywords: Fipronil, Fipronil-sulfide, Fipronil-sulfone, Fipronil-desulfinyl, chicken egg, LC-MS/MS

\section{INTRODUCTION}

Fipronil developed by the Company Rhone-Poulenc Ag (now Bayer Crop Science) in 1987 [1] is one of the high effective insecticides belonging to the phenylpyrazole group. Fipronil shows great sensitivity to insects combating cyclopentadiene, organic phosphorus, organic chlorine, pyrethroids, and carbamate pesticides. In addition, none of cross resistance of fipronil to existing pesticides was recorded. Therefore, it is widely used to control numerous pests and diseases in crops such as rice, vegetables [2,3], cotton [4], etc.

Inspite of high effectiveness, fipronil is a toxin which degrades quickly into other form including fipronil sulfone, fipronil sulfide, desulfinyl fipronil and fipronil amide in redox, photochemical and hydrolysis procesess (Figure 1) [5]. Some of the metabolites are harmful to the environment and toxin to humans than fipronil itself [6]. Desulfinylfipronil is formed through photodegradation in water and in soil. Fipronil sulfide is formed through degradation in soil and water under anaerobic conditions and is more toxic than fipronil to freshwater invertebrates. Fipronil sulfone is formed through aerobic soil metabolism and is much more toxic to avian species, freshwater fish and invertebrates than the parent compound [7].

In 2017, the European Commissioner for Health and Food Safety, Vytenis Andriuka, announced that 26 out of 28 member states of EU reported detection of fipronil in eggs and egg products. More than 45 countries were also affected all over the world including the United States, 
Russia, Israel and Canada [8]. Fipronil was mixed with other pesticides and sprayed on chickens to prevent ticks, fleas and lice, resulted in the accumulation of the chemical in meat and eggs. It was reported that total fipronil and fipronil sulfone residues in several samples (up to $1.2 \mathrm{mg} / \mathrm{kg}$ ) were significantly higher than the MRL of the EU $(0.005 \mathrm{mg} / \mathrm{kg})[9]$.

Figure 1. Fipronil and its metabolites
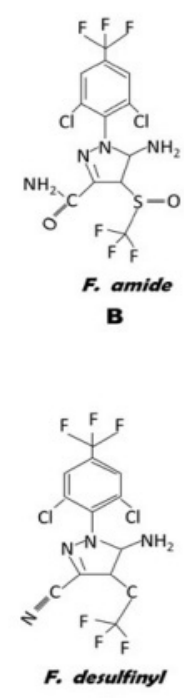

c
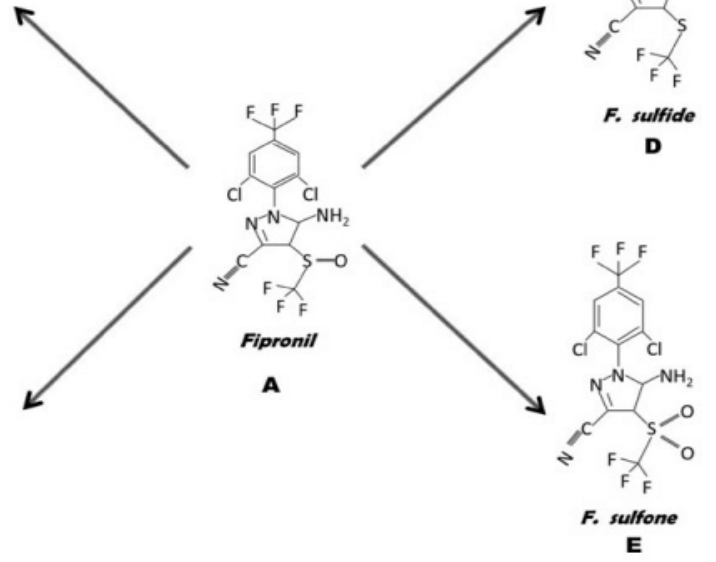

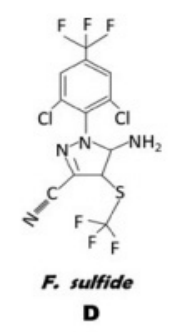

Currently, the number of methods has been studied to analyze trace amounts of fipronil and its metabolites on different matrices. Hainzl and Casida used GC/MS to identify fipronil and metabolites in plant extracts [10], Li et al. studied residues of pipronil in peanuts and soil samples extracted by QuEChERS and analyzed by LC-MS/MS [11]. Had-jmohammadi et al. employed liquid extraction and soxhlet to extract fipronil in water and soil samples, analyzed by reverse-phase high-performance liquid chromatography (RP-HPLC) [12]. Paramasivam and Chandrasekaran developed methods to identify fipronil and metabolites in vegetables, fruits, and soil through the process of preparing QuEChERS samples [3].

In this study, the research group developed a simple, highly sensitive and reliable method in order to determine fipronil and its metabolites residue in chicken eggs by using LC-MS/MS. The samples randomly collected in local markets were analyzed by using the optimized method.

\section{MATERIALS AND METHOD}

\subsection{Materials}

Blank: Chicken eggs were randomly sampled at supermarkets in Ho Chi Minh City.

Practical samples: 10 chicken egg samples were taken from traditionally retail markets in Ho Chi Minh City.

\subsection{Chemicals and equipment}

Standards: Fipronil 98.7\% (Dr.Ehrenstorfer GmbH), Fipronil-desulfinyl 96.5\% (Dr.Ehrenstorfer $\mathrm{GmbH}$ ), Fipronil sulfide 99.3\% (Dr.Ehrenstorfer $\mathrm{GmbH}$ ), Fipronil sulfone 98.2\% (Dr.Ehrenstorfer $\mathrm{GmbH})$.

Reagents: Acetonitril and Methanol (LC-MS, Fisher); DisQuETM Pouch for $50 \mathrm{~mL}$ CEN salt; Oasis PriME HLB cartridge Plus Light (100 mg); deionized water.

Equipment: Thermo Scientific UHPLC Ultimate 3000, Spectrometric connectivity TSQ Quantum access MAX with ESI ionization (-). 


\subsection{Method}

Firstly, the shells were removed, the remained egg white and egg yolk were homogenized with a homogeneous sample machine. Secondly, samples were weighed, extracted with water and ACN, added with salt DisQuetM Pouch and centrifuged. After that, the centrifuged ACN layers were taken and cleaned by using the Oasis PriME HLB filter. Finally, the filtrates were analyzed by means of a liquid mass spectrometry twice.

In the MRM mode, the two product ions with the highest sensitivity and optimal selectivity were selected to verify every result. The ion with the higher response was used for quantification, and the less intense ion signal and the retention times were used for qualification.

\section{RESULTS AND DISCUSSION}

\subsection{LC-MS/MS Conditions}

\subsubsection{Mass spectral conditions $M S / M S$}

In this study, precusor and product ions of fipronil and its metabolytes were selected by direct injection of $5.0 \mu \mathrm{g}$ composite standard $/ \mathrm{mL}$ in ACN at different ESI cone voltages and the higher sensitivity in the ESI ${ }^{-}$mode was observed. The results were shown in Table 1.

Table 1. The optimal ESI (-) parameters of fipronil and its metabolites

\begin{tabular}{|c|c|c|c|}
\hline Compound & $\begin{array}{c}\text { Precusor ion } \\
(\mathrm{m} / z)\end{array}$ & Product ion $(m / z)$ & $C E$ \\
\hline Fipronil-desulfinyl & 386.9 & $\frac{351.0^{*}}{282.0}$ & $\begin{array}{l}10 \\
35 \\
\end{array}$ \\
\hline Fipronil & 434.9 & $\frac{330.0^{*}}{250.0}$ & $\begin{array}{l}17 \\
27\end{array}$ \\
\hline Fipronil-sulfide & 418.9 & $\frac{262.0^{*}}{383.0}$ & $\begin{array}{l}30 \\
10\end{array}$ \\
\hline Fipronil-sulfone & 450.9 & $\frac{415.0^{*}}{282.0}$ & $\begin{array}{l}15 \\
35\end{array}$ \\
\hline
\end{tabular}

\subsubsection{High-performance liquid chromatographic conditions}

The Agilent poroshell column $120 \mathrm{EC}-\mathrm{C} 18(2.7 \mu \mathrm{m}, 2.1 \times 100 \mathrm{~mm})$ and the Agilent pre-column were used for analysis. The mobile phase composition for the chromatographic separation of fipronil and its metabolites was optimaized using $\mathrm{MeOH}-\mathrm{H}_{2} \mathrm{O}$.

The resolution of the separation system followed the gradient program as given in Table 2 with the flow rate at $0.3 \mathrm{~mL} / \mathrm{min}$ and the injection volume of $2 \mu \mathrm{L}$. The chromatograms of mix standards were shown in Figure 2.

Table 2. The gradient program has been optimized for separation

\begin{tabular}{|c|c|c|c|}
\hline Time (minute) & Flow $(\mathbf{m L} /$ min) & \% $\boldsymbol{A}$ & \% B \\
\hline $0 \rightarrow 3.0$ & 0.3 & 60 & 40 \\
\hline $3.0 \rightarrow 7.0$ & 0.3 & 70 & 30 \\
\hline $7.0 \rightarrow 9.5$ & 0.4 & 60 & 40 \\
\hline $9.5 \rightarrow 10.0$ & 0.3 & 60 & 40 \\
\hline
\end{tabular}




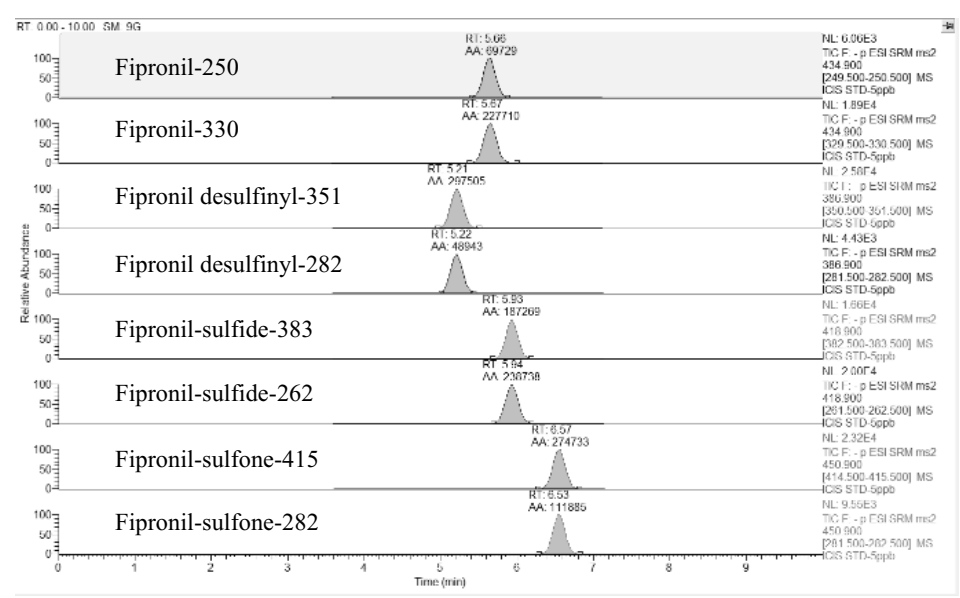

Figure 2. Blank spiked sample chromatogram $(5.0 \mu \mathrm{g} / \mathrm{mL})$

\subsection{Sample preparation}

The amount of 5.0 grams of homogenous egg was weighed and put into a $50 \mathrm{~mL}$ centrifugal tube. Then, $10 \mathrm{~mL} \mathrm{H}_{2} \mathrm{O}$ was added and the tube was shaken within 1 minute. Next, $10 \mathrm{~mL}$ ACN was added, the tube was shaken within one minute. After that, DisQuE salt was added and the tube was shaken within one minute. The mixture was then centrifuged at $6,000 \mathrm{rpm}$ in five minutes at room temperature, and $2.0 \mathrm{~mL}$ of the supernatant was aspirated by passing the Oasis PriME HLB filter. Finally, $1.0 \mathrm{~mL}$ of the filtrate was put into a two $\mathrm{mL}$ vial and the filted solution was analyzed by LC-MS/MS.

\subsection{Validation}

\subsubsection{Matrix effects}

In mass spectrometry, the signal strength of the ion fragments is influenced by the sample matrix. Therefore, it is necessary to assess the matrix effect of tandem mass spectrometry. In this study, matrix effects were evaluated by adding standards to the final extract solution (post-spike) and calculating the recovery rate.

Blank samples were treated according to the developed procedure. This step was carried out twice. Firstly, $0.98 \mathrm{~mL}$ of the filtrate and $0.02 \mathrm{~mL}$ of the $250 \mu \mathrm{g} / \mathrm{mL}$ standard mixture was mixed. Then, the mixture was analyzed by means of LC-MS/MS. Obtained data was used to assess the matrix effects. Table 3 showed that the recovery rate nearly reached $100 \%$. It means that there were no matrix effects.

Table 3. Recovery and relative repeatability of spiked samples

\begin{tabular}{|c|c|c|c|c|c|}
\hline \multicolumn{2}{|c|}{ Sample } & $\begin{array}{c}\text { Standard } \\
\text { theoretical } \\
\text { concentration } \\
(\mu \mathrm{g} / \mathrm{kg})\end{array}$ & $\begin{array}{c}\text { Amount } \\
(\mu \mathrm{g} / \mathrm{kg})\end{array}$ & RSD (\%) & $\begin{array}{c}\text { Recovery } \\
(\%)\end{array}$ \\
\hline & Blank & 0 & 0 & 0 & 0 \\
\hline \multirow{4}{*}{$\begin{array}{l}\text { Post- } \\
\text { spike }\end{array}$} & Fipronil-desulfinyl & \multirow{4}{*}{10.0} & 10.71 & 1.00 & 107.08 \\
\hline & Fipronil & & 10.74 & 4.07 & 107.43 \\
\hline & Fipronil-sulfide & & 10.56 & 7.95 & 105.59 \\
\hline & Fipronil-sulfone & & 10.68 & 4.36 & 106.84 \\
\hline
\end{tabular}




\begin{tabular}{|c|c|c|c|c|c|}
\hline \multirow{4}{*}{$\begin{array}{l}\text { Pre- } \\
\text { spike }\end{array}$} & Fipronil-desulfinyl & \multirow{4}{*}{5.0} & 4.69 & 5.30 & 93.76 \\
\hline & Fipronil & & 5.14 & 1.63 & 102.86 \\
\hline & Fipronil-sulfide & & 5.04 & 3.23 & 100.83 \\
\hline & Fipronil-sulfone & & 4.83 & 4.31 & 96.66 \\
\hline
\end{tabular}

\subsubsection{Specificity}

In this study, every substance was characterized by a precusor ion and two product ions. Therefore, the IP score of each subtance was four and that met the requirements of the European Council (EC) for the recognition of the chromatographic peak. The blank samples were analyzed and did not show any signals of the analyte, while blank spiked samples showed signals with appropriate retention time at $5.0 \mu \mathrm{g} / \mathrm{kg}$. Therefore, this method was demonstrated to be high specificity.

\subsubsection{Linearity}

Working standard solutions of fipronil and its metabolites $(1 \mathrm{mg} / \mathrm{mL})$ were prepared in ACN. Solutions of standards were prepared over the range of 0.5 to $10.0 \mu \mathrm{g} / \mathrm{mL}$ according to working standard solutions, soluted by ACN and stored at $4{ }^{\circ} \mathrm{C}$. The acceptance criterion was that the coeffcient correlation $\left(\mathrm{R}^{2}\right)$ must be higher than 0.99 .

The linearity of the chromatographic response was assessed with calibration curve at five different concentration levels and shown in Table 4 . The calibration curve (From 0.5 to $10.0 \mu \mathrm{g} / \mathrm{mL}$ ) showed good linearity with correlation coefficient $\left(\mathrm{R}^{2}\right)>0.99$.

Table 4. Calibration curves and correlation coefficients of fipronil and its metabolites

\begin{tabular}{|c|c|c|c|}
\hline Compound & $\begin{array}{c}\text { Concentration range } \\
(\boldsymbol{\mu g} / \boldsymbol{m} \boldsymbol{L})\end{array}$ & Calibration curves & $\begin{array}{c}\text { Correlation } \\
\text { coefficients }\end{array}$ \\
\hline \multirow{2}{*}{ Fipronil-desulfinyl } & \multirow{3}{*}{$0.5-10.0$} & $\mathrm{y}=72,822 * \mathrm{x}-6,843.1$ & 0.9983 \\
\hline Fipronil & $\mathrm{y}=36,727 * \mathrm{x}+11,277$ & 0.9966 \\
\cline { 1 - 2 } \cline { 4 - 4 } Fipronil-sulfide & & $\mathrm{y}=40,380 * \mathrm{x}-7,180.4$ & 0.9967 \\
\hline Fipronil-sulfone & & $\mathrm{y}=46,234 * \mathrm{x}-16,166$ & 0.9970 \\
\hline
\end{tabular}

\subsubsection{Limit of detection (LOD) and Limit of quantification (LOQ)}

Fipronil and its metabolites standards were added into the blank to the concentration of 1.0 $\mu \mathrm{g} / \mathrm{kg}$ and analyzed by developed procedures. The test was repeated 10 times. Then, the results were calculated the average value of 10 samples (x) and standard deviation (SD). After that LOD was calculated by the formula: $\mathrm{LOD}=3 \mathrm{x} \mathrm{SD}$, this $\mathrm{LOD}$ was evaluated by calculating the $\mathrm{R}=\mathrm{x} / \mathrm{LOD}$, if $4<\mathrm{R}<10$, the concentration of the tested solution is appropriate, the calculated LOD is reliable and LOQ $=10 \times$ SD [14]. LOD and LOQ were calculated and presented in Table 5. The LOD and LOQ of fipronil and its metabolites were low (aproximately $0.2 \mu \mathrm{g} / \mathrm{kg}$ and $0.6 \mu \mathrm{g} / \mathrm{kg}$, respectively).

Table 5. $L O D, L O Q$, recovery and $R S D \%$ of fipronil and its metabolites

\begin{tabular}{|c|c|c|c|c|c|c|c|c|}
\hline Compound & $\begin{array}{c}\text { Theoretic } \\
\text { standard } \\
\text { concentration } \\
(\mu \mathrm{g} / \mathrm{kg})\end{array}$ & $\begin{array}{c}\text { Amount } \\
(\mu \mathrm{g} / \mathrm{kg})\end{array}$ & $\begin{array}{c}\text { Deviation } \\
\text { SD }\end{array}$ & $\begin{array}{c}\text { RSD } \\
\%\end{array}$ & $\begin{array}{c}\text { Recovery } \\
(\%)\end{array}$ & $\begin{array}{c}\text { LOD } \\
(\mu \mathrm{g} / \mathrm{kg})\end{array}$ & $\begin{array}{c}\text { LOQ } \\
(\mu \mathrm{g} / \mathrm{kg})\end{array}$ & $\boldsymbol{R}$ \\
\hline $\begin{array}{c}\text { Fipronil- } \\
\text { desulfinyl }\end{array}$ & & 0.95 & 0.06 & 6.80 & 95.28 & 0.18 & 0.60 & 5.28 \\
\hline
\end{tabular}




\begin{tabular}{|c|c|c|c|c|c|c|c|c|}
\hline \multirow{2}{*}{ Fipronil } & 0.92 & 0.05 & 5.77 & 92.23 & 0.15 & 0.50 & 6.13 \\
\hline $\begin{array}{c}\text { Fipronil- } \\
\text { sulfide }\end{array}$ & 1.0 & 1.00 & 0.07 & 11.36 & 100.45 & 0.21 & 0.70 & 4.76 \\
\hline $\begin{array}{c}\text { Fipronil- } \\
\text { sulfone }\end{array}$ & & 0.99 & 0.07 & 10.86 & 95.98 & 0.21 & 0.70 & 4.71 \\
\hline
\end{tabular}

\subsubsection{Repeatability and reproducibility}

The blank samples were spiked with fipronil and its metabolites each at 2.0, 5.0 and $10.0 \mu \mathrm{g} / \mathrm{kg}$. Developed procedures were used for analysis. Repeatability was tested by analysing seven replicates of blank samples spiked at three concentration levels. Reproducibility was determined for the same concentration, the test was repeated every three days.

In this study, the repeatability of fipronil and its metabolites ranged from $1.63 \%$ to $9.23 \%$ for both days and the reproducibility ranged from $2.59 \%$ to $7.47 \%$, the recovery ranged from $93.24 \%$ to $107.89 \%$ (Table 6). Furthermore, the average recoveries obtained at all concentrations and conditions were above $90 \%$ in all samples. These results meet the requirements of AOAC.

Table 6. Recovery rate and relative repeatability of blank spiked sample

\begin{tabular}{|c|c|c|c|c|c|c|}
\hline Compound & $\begin{array}{c}\text { Additional } \\
\text { standard } \\
\text { concentration } \\
(\mu \mathrm{g} / \mathrm{kg})\end{array}$ & $\begin{array}{c}\text { First time } \\
R S D_{r} \%\end{array}$ & $\begin{array}{l}\text { First time } \\
\text { recovery \% }\end{array}$ & $\begin{array}{c}\text { Second } \\
\text { time } \\
\text { RSD }_{r} \%\end{array}$ & $\begin{array}{c}\text { Second time } \\
\text { recovery } \%\end{array}$ & $R S D_{R} \%$ \\
\hline \multirow{3}{*}{$\begin{array}{l}\text { Fipronil- } \\
\text { desulfinyl }\end{array}$} & 2.0 & 6.46 & 96.37 & 4.41 & 96.18 & 5.32 \\
\hline & 5.0 & 5.30 & 93.76 & 6.05 & 95.36 & 5.54 \\
\hline & 10.0 & 4.33 & 97.70 & 4.73 & 97.43 & 4.36 \\
\hline \multirow{3}{*}{ Fipronil } & 2.0 & 9.23 & 94.61 & 5.87 & 93.60 & 7.47 \\
\hline & 5.0 & 1.63 & 102.86 & 4.17 & 100.51 & 3.25 \\
\hline & 10.0 & 3.36 & 104.16 & 3.36 & 99.61 & 3.96 \\
\hline \multirow{3}{*}{$\begin{array}{l}\text { Fipronil- } \\
\text { sulfide }\end{array}$} & 2.0 & 5.40 & 96.90 & 8.12 & 92.69 & 6.96 \\
\hline & 5.0 & 3.23 & 100.83 & 5.38 & 95.82 & 4.98 \\
\hline & 10.0 & 6.31 & 107.89 & 4.59 & 106.88 & 5.33 \\
\hline \multirow{3}{*}{$\begin{array}{l}\text { Fipronil- } \\
\text { sulfone }\end{array}$} & 2.0 & 3.85 & 93.24 & 5.76 & 93.24 & 4.72 \\
\hline & 5.0 & 4.31 & 96.66 & 2.51 & 98.19 & 3.47 \\
\hline & 10.0 & 2.69 & 99.20 & 2.70 & 99.00 & 2.59 \\
\hline
\end{tabular}

\subsection{Real sample analysis}

Samples were randomly taken from 10 traditional retailed markets in Ho Chi Minh City. According to developed procedure, the analytical results revealed that there were eight samples of fipronil infection, two samples infected with fipronil sulfone, no sample infected with fipronil sulfide and desulfinyl fipronil. However, the residues of fipronil were found to be lower than the allowable limit (5.0 $\mu \mathrm{g} / \mathrm{kg}$ according to EC). The method efficiency achieved high reliability was shown in Table 7. 
SCIENTIFIC RESEARCH

Table 7. Results of fipronil and its metabolitest contents in pearl samples

\begin{tabular}{|c|c|c|c|c|}
\hline Compound & $\begin{array}{c}\text { Fipronil-desulfinyl } \\
\text { concentration } \\
\boldsymbol{\mu g} / \mathbf{k g} / \text { recovery } \%\end{array}$ & $\begin{array}{c}\text { Fipronil } \\
\text { concentration } \\
\boldsymbol{\mu g} / \mathbf{k g} / \text { recovery } \\
\boldsymbol{\%}\end{array}$ & $\begin{array}{c}\text { Fipronil-sulfide } \\
\text { concentration } \boldsymbol{\mu g} / \mathbf{k g} \\
\text { /recovery } \\
\boldsymbol{\%}\end{array}$ & $\begin{array}{c}\text { Fipronil-sulfone } \\
\text { concentration } \boldsymbol{\mu g} / \boldsymbol{k} \\
\text { /recovery } \\
\boldsymbol{\%}\end{array}$ \\
\hline Sample 1 & KPH (96.78) & $0.7(98.78)$ & KPH (92.11) & KPH (96.12) \\
\hline Sample 2 & KPH (93.15) & $1.3(95.71)$ & KPH (97.15) & $0.8(99.15)$ \\
\hline Sample 3 & KPH (98.10) & $1.1(102.34)$ & KPH (101.35) & KPH (102.82) \\
\hline Sample 4 & KPH (95.45) & $0.9(96.91)$ & KPH (106.81) & KPH (97.74) \\
\hline Sample 5 & KPH (103.52) & KPH (98.70) & KPH (96.10) & KPH (96.15) \\
\hline Sample 6 & KPH (101.13) & $1.1(92.46)$ & KPH (99.45) & $0.6(99.23)$ \\
\hline Sample 7 & KPH (92.77) & $0.8(96.46)$ & KPH (93.51) & KPH (92.11) \\
\hline Sample 8 & KPH (94.80) & $1.5(99.81)$ & KPH (90.35) & KPH (90.68) \\
\hline Sample 9 & KPH (98.57) & KPH (103.41) & KPH (96.88) & $1.2(96.48)$ \\
\hline Sample 10 & KPH (102.59) & $0.9(95.49)$ & KPH (98.58) & KPH (101.58) \\
\hline KPH: Not detected & & & \\
\hline
\end{tabular}

\section{CONCLUSIONS}

The study has successfully developed a method to determine the residue of fipronil and its metabolites in chicken eggs by using LC-MS/MS. This methodology showed linearity from 0.5 to $10.0 \mu \mathrm{g} / \mathrm{kg}$ with good regression coefficient $\left(\mathrm{R}^{2} \geq 0.996\right)$ for all analytes. The simple sample preparation was demonstrated by recovery rate at $93-108 \%$ and RSD of less than $10.0 \%$ at three spiked concentration levels. The method presented here provided excellent resolution and sensitivity for the quantification of fipronil and its metabolites in eggs and met the analytical needs for food safety laboratories. The method was applied to analyze 10 samples of chicken eggs collected in Ho Chi Minh City. It was obvious that the possibility of fipronil infection would be actually high, even though its content was relatively low. Therefore, it is necessary to strictly check the controlling process of egg production and consumption.

\section{REFERENCES}

1. C.C.D. Tingle, J.A. Rother, C.F. Dewhurst, S. Lauer, W.J. King, "Fipronil: environmental fate, ecotoxicology, and human health concerns", Rev. Environ.Contam. Toxicol., vol. 167, Springer, New York, 2003, pp. 1-66.

2. G. Balan, ccedil, Marie-No, eumL, 1.d. Visscher, Effects of very low doses of fipronil on grasshoppers and non-target insects following field trials for grasshopper control, Crop Protection, 16, 1997, 553.

3. M. Paramasivam, S. Chandrasekaran, "Determination of fipronil and its major metabolites in vegetables, fruit and soil using QuEChERS and gas chromatography-mass spectrometry", Int. J. Environ. Anal. Chem. 93, 2012, 1203.

4. R.K. Mensah, L. Austin, "Microbial control of cotton pests. Part I: Use of the naturally oc curring entomopathogenic fungus Aspergillus sp. (BC 639) in the management of Creontiades 
dilutus (Stal) (Hemiptera: Miridae) and beneficial insects on transgenic cotton crops", Biocontrol Sci. Technol. 22, 2012, 567.

5. A.S. Gunasekara, T. Truong, K.S. Goh, F. Spurlock, R.S. Tjeerdema, "Environmental fate and toxicology of fipronil", J. Pestic. Sci.32, 2007, 189.

6. Bobe' A, Cooper J-F, Coste CM, Muller M-A, Behaviour of Fipronil in soil under Sahelian Plain field conditions. Pestic Sci 52(3), 1998, 275-281.

7. U.S.Enviromental Protection Agency, Fipronil: Washington, D.C., Office of Prevention, Pes ticides, and Toxic Substances, New Pesticide Fact Sheet, 1996, 8.

8. Fipronil in eggs: Fact sheet -December 2017, European Union, 2018 - JRC110632.

9. Commission Regulation (EU) No 1127/2014 of 20 October 2014 amending Annexes II and III to Regulation (EC) No 396/2005 of the European Parliament and of the Council as regards maximum residue levels for amitrole, dinocap, fipronil, flufenacet, pendimethalin, propyzamide, and pyridate in or on certain products Text with EEArelevance

10. Hainzl, Dominik, and Casida, J.E., "Fipronil insecticide-Novel photochemical desulfinylation with retenion of neurotoxicity", Proceedings of the National Academy of Sciences of the United States of America, v.93, 1996, p. 12764 - 12767.

11. M. Li, P. Li, L. Wang, M. Feng, L. Han, "Determination and Dissipation of Fipronil and Its Metabolites in Peanut and Soil", J. Agric. Food Chem. 16, 2015, 4435.

12. M.R. Hadjmohammadi, S.M. Nikou, K. Kamel, "Determination of Fipronil Residue in Soil and Water in the Rice Fields in North of Iran by RP-HPLC Method", Acta Chim. Slov. 53, 2006, 517.

13. Tran Cao Son, Pham Xuan Đa, Le Thi Hong Hao, Nguyen Thanh Trung, "Method validation in analysis of chemistry and microbiology", Poublishing house of Science and Technology, Hanoi, 2010, Hà Nội.

\section{Tóm tắt}

\section{PHÂN TÍCH FIPRONIL VÀ CÁC CHẤT CHUYỄN HÓA CỦA FIPRONIL}

\section{TRONG TRÚNG BẰNG LC-MS/MS}

\section{Nguyễn Hương Giang ${ }^{1,2}$, Đỗ Ngọc Nhân ${ }^{1,2}$, Phạm Văn Sơn ${ }^{3}$}

Trung tâm Kiểm nghiệm Thuốc, Mỹ phẩm, Thực phẩm TP. Hồ Chi Minh ${ }^{1}$

Khoa Kỹ thuật Hóa học, Truờng Đại học Bách Khoa, Đại học Quốc gia TP. Hồ Chí Minh²

Ban Quản lý An toàn thưc phầm TP. Hồ Chí Minh ${ }^{3}$

Trong nghiên cứu này, chúng tôi đã xây dựng phương pháp phân tích fipronil và các chất chuyển hóa của fipronil trong trứng gà bằng phương pháp sắc ký lỏng khối phổ (LC-MS/MS). Mẫu trứng gà được chiết bằng phương pháp QuEChERS, dịch được làm sạch qua đầu lọc Oasis và phân tích bằng LC-MS/MS. Kết quả thẩm định phương pháp cho thấy hệ số tương quan tuyến tính tốt $\left(\mathrm{R}^{2}>0.99\right)$ với đường chuẩn nồng độ từ 0,5 đến $10,0 \mu \mathrm{g} / \mathrm{kg}$. Độ thu hồi trung bình của fipronil và các chất chuyển hóa tại ba mức nồng độ thêm chuân 2,$0 ; 5,0$ và $10,0 \mu \mathrm{g} / \mathrm{kg}$ khoảng từ $93,24 \%$ đến $107,89 \%$, độ lặp lại thấp hơn $9,2 \%$. LOQ của phương pháp là $0,6 \mu \mathrm{g} / \mathrm{kg}$ và LOD là $0,2 \mu \mathrm{g} / \mathrm{kg}$. Phương pháp đơn giản, có độ đặc hiệu và tin cậy cao đã áp dụng để phân tích fipronil và các chất chuyển hóa trên mẫu thực.

Tù khóa: Fipronil, Fipronil-sulfide, Fipronil-sulfone, Fipronil-desulfinyl, trúng gà, $L C-M S / M S$ 